\title{
STABILITY AND AVAILABILITY OF GOODS ON THE MARKET IN TIMES OF CRISIS 2020 (COVID-19 CRISIS) - SECURITY OF SUPPLY IN EVERYDAY LIFE
}

doi: $10.2478 /$ czoto-2021-0010

Date of submission of the article to the Editor: 29/11/2020

Date of acceptance of the article by the Editor: $31 / 03 / 2021$

Dorota Klimecka-Tatar ${ }^{1}$ - orcid id: 0000-0001-6212-6061

Olga Kiriliuk ${ }^{2}$ - orcid id: 0000-0001-7892-6987

Natalia Baryshnikova ${ }^{3}$ - orcid id: 0000-0002-6645-8212

${ }^{1}$ Czestochowa University of Technology - Poland

2Omsk State Transport University - Russian Federation

${ }^{3}$ Saratov State Law Academy - Russian Federation

Abstract: The sudden introduction of restrictions related to the pandemic situation caused by the new SARS-COV-2 of virus causing COVID-19 had a significant impact on people's lives. Limited access to products and services has caused chaos in the market. The goal of this paper is to find out the opinion on the resulting limitations in access to everyday products - during the period of partial lockdown. Based on the research, it was found that during the lockdown caused by the epidemic situation (COVID-19), people feel limited access to some products of everyday life, which in turn has an impact on their sense of anxiety and security. People noted the greatest limited availability of food products and in particular fresh fruit and vegetables, also reported limited access to pharmaceuticals. Furthermore, people confirmed that as the main reasons for anxiety and insecurity are the limited access to food products and to pharmaceuticals.

Keywords: crisis 2020, COVID-19, trade stability, supply security, goods availability

\section{INTRODUCTION}

Generally, the term crisis refers to a specific event or period of time that results in the loss of stability and the emergence of threats directly affecting an individual, group or society as a whole. Simplifying, crisis is an extraordinary situation, often unforeseen, the shortcomings of which are difficult to predict - a situation that is extremely difficult or dangerous, when there are a lot of parallel problems.

Despite the fact that many scientists predicted the coming crisis in 2020 caused by the emergence of a new variant of the SARS-COV-2 virus causing COVID-19, it was difficult to predict to what extent its effects would directly affect the average citizen. Furthermore, information about the high degree of crisis risk posed by biological hazards, most societies were unaware of how this would affect their immediate daily lives. Usually, when speaking of a crisis, people think of an economic crisis which is the 
effect of an economy (global market) balancing on the verge of profitability (Baryshnikova et al., 2020; Baryshinkova et al., 2021; Chen, et al., 2020). This type of crisis obviously affects the lives of citizens, but its impact is not as direct as it is during the 2020 crisis (Albonico and Tirelli, 2020). The size and extent of the crisis in terms of product demand and labour demand can only be determined by comparing the precrisis situation, during its duration, using a combination of specific employment data and public procurement volumes (Gajdzik and Wolniak, 2021; Gugler et al., 2020; Ritter and Pedersen, 2020).

In recent years (last decade), the economy has undergone continuous development and growth, the labour market, thanks to the boom, was determined by the requirements of customers and employees. The effect of which was a significant increase in average earnings and improvement in living conditions (mainly in highly industrialized or developing countries). In recent years, both the manufacturing and service industries have focused their activities on processes improvement, and not only keeping them at a minimum (profitable) level (Čierna and Sujová, 2020; Klimecka-Tatar and Ingaldi, 2020; Knop, 2020; Kowalik, 2020; Labajan and Koomsap, 2019; Pietraszek, et al., 2020; Rosak-Szyrocka and Abbase, 2020; Wawrowski and Otola, 2020). In the last 10 years, more convenient forms of meeting customer requirements (changing the form of business, sales and internet services) have been sought rather than searching for any channels of the customer reaching (Ingaldi and Ulewicz, 2019). The COVID-19 pandemic is significantly affecting global economies. According to the World Trade Organization (WTO), the economic consequences are serious, and it is predicted that the flow of goods could be reduced by more than $30 \%$ (Blenkinsop, 2020). Moreover, at the end of 2020 , it is still not possible to say that the situation has been brought under control to some extent, what is more, the crisis is still under development. Many companies suffer from total or partial blockage as a result of COVID-19 restrictions, such destructive business freezing is particularly relevant to the service industry (Bove and Benoit, 2020; Ingaldi and Brožovà, 2020; Lang et al., 2020; Le and Phi, 2020; O'Hara and Toussaint, 2021; Ritchie and Jiang, 2019).

The results presented by Ritter and Pedersen (2020) show that the impact of the 2020 crisis on companies is very different. The authors also emphasize that understanding these differences is crucial for developing strategies in times of crisis but also for successfully navigating into the future (Ritchie and Jiang, 2019). However, the essence of dealing with the consequences of each crisis is the introduction of a supply chain management strategy, financial management, implementation of emergency procedures and improvement of communication. In the time of the global "COVID-2020 crisis", supply chains for medical equipment - managing the demand and supply of medical equipment - deserve special attention (Burdekin and Tao, 2020; Contreras et al., 2020; Moyo, 2020; Nakat and Bou-Mitri, 2021; Okeagu et al., 2020). However, the demand and supply of other goods commonly used by citizens cannot be ignored. It also deserves attention, the availability of goods that are a typical need of society: fresh food (e.g. vegetables, fruit, bread, dairy products), medicines, personal and industrial chemicals e.t.c. The availability of these products can be said to provide security of supply in everyday life.

This paper highlights the stability of supplies and the availability of various groups of products and services in the light of the freezing of the economy due to the epidemic. The paper describes the impact of the limited availability of everyday goods on the sense of security among the society. 


\section{METHODOLOGY OF RESEARCH}

The effect of the limited availability of products (products of everyday life) on people's sense of security was determined on the basis of the survey results. The research was carried out in the period from April to October 2020 - this period included national quarantine (in many countries). The survey has an electronic form (via the Internet). The first part of the questionnaire helped to characterize respondents in terms of nationality, age, gender, education, place of residence and social status. The second part of the questionnaire was consisted of 10 questions aimed at identifying a limitation in the availability of everyday products (Q1-10). While the third part (Q11-Q15) focused on anxiety and a disturbed sense of security.

Questions in the second part of the questionnaire:

Q1. Is the availability of bread limited?

Q2. Is the availability of fresh vegetables and fruit limited?

Q3. Is the availability of dairy products limited?

Q4. Is the availability of meat products limited?

Q5. Is the availability of household chemicals limited?

Q6. Is the availability of hygiene products limited?

Q7. Is the availability of pharmaceuticals limited?

Q8. Is the availability of supplements limited?

Q9. Is the availability of tobacco and alcohol products limited?

Q10. Is the availability of clothing products limited?

Questions in the third part of the questionnaire:

Q11. Do you feel insecure due to the limited availability of food products?

Q12. Do you feel insecure due to the limited availability of pharmaceutical products?

Q13. Do you feel insecure due to the limited availability of household chemicals?

Q14. Do you feel insecure due to the limited availability of hygiene products?

Q15. Do you feel insecure due to the limited availability of clothing products?

The respondents estimated the availability of products on the basis of a 5-point Likert scale. Where 1 means - "I did not feel limited availability at all", 5 means - "I felt limited availability very much". Similarly, they assessed the sense of security: in this case 1 means - "I feel very safe", 5 means - "I feel very great danger".

During the study, 539 questionnaires were collected, of which only 510 were correctly completed - and only these were taken into account when analysing the results. Table 1 presents the general characteristics of the respondents' group. Most of the respondents were from Poland, Russia, Slovakia and the Czech Republic. The respondents also included citizens of Italy, Slovenia, Germany and Spain.

Table 1 presents the characteristics of the respondents in the form of a numerical statement and a percentage structure. As it is easy to see, the vast majority of the respondents were people under the age of 50 (people aged 21-35 constituted $41.37 \%$ of the respondents, and people aged 36-50 - as much as $37.06 \%$ ). Most of the respondents were women. And most people have vocational and secondary education (30.20\% vocational education, $36.86 \%$ secondary education). A statistical respondent is a resident of a city with a population less than $400 \mathrm{k}$ residents. With regard to the social position (based on monthly income per family inhabitant), it was noticed that the respondents refused to answer $(66.47 \%$ no answer), and among those who answered respondents were mainly people with less than EUR 400 per family member monthly. 
Table 1

Characteristics of the respondents by: age, gender, education, place of residence, social status, monthly earnings per family member

\begin{tabular}{|c|c|c|c|c|}
\hline \multicolumn{3}{|c|}{ Characteristics of respondents } & \multirow{2}{*}{$\begin{array}{r}\begin{array}{c}\text { Number of } \\
\text { respondents }\end{array} \\
35\end{array}$} & \multirow{2}{*}{$\begin{array}{l}\begin{array}{l}\text { Percentage } \\
\text { structure }\end{array} \\
6.86\end{array}$} \\
\hline \multirow{5}{*}{ F1 } & \multirow{5}{*}{ age } & up to 20 years & & \\
\hline & & 21-35 years & 211 & 41.37 \\
\hline & & $35-50$ years & 189 & 37.06 \\
\hline & & $51-65$ years & 52 & 10.20 \\
\hline & & Over 65 years old & 23 & 4.51 \\
\hline \multirow{2}{*}{ F2 } & \multirow{2}{*}{ gender } & male & 312 & 61.18 \\
\hline & & female & 198 & 38.82 \\
\hline \multirow{5}{*}{ F3 } & \multirow{5}{*}{ education } & primary education & 35 & 6.86 \\
\hline & & lower secondary education & 99 & 19.41 \\
\hline & & vocational education & 154 & 30.20 \\
\hline & & secondary education & 137 & 26.86 \\
\hline & & higher education & 85 & 16.67 \\
\hline \multirow{5}{*}{ F4 } & \multirow{5}{*}{ place of residence } & village & 105 & 20.59 \\
\hline & & city up to $50 \mathrm{k}$ residents & 132 & 25.88 \\
\hline & & city 51 to $200 \mathrm{k}$ residents & 128 & 25.10 \\
\hline & & city 201 to $400 k$ residents & 111 & 21.76 \\
\hline & & city with over $400 \mathrm{k}$ residents & 34 & 6.67 \\
\hline \multirow{5}{*}{ F5 } & \multirow{5}{*}{$\begin{array}{c}\text { social status, } \\
\text { monthly earnings } \\
\text { per family } \\
\text { member }\end{array}$} & no answer & 339 & 66.47 \\
\hline & & up to 200 euros per member & 68 & 13.33 \\
\hline & & 201-400 euros per member & 74 & 14.51 \\
\hline & & 401-600 euros per member & 18 & 3.53 \\
\hline & & above 601 euros per member & 11 & 2.16 \\
\hline
\end{tabular}

Source: own study

\section{RESULTS AND DISCUSSION}

Tables 2 and 3 present the general statistical characteristics of the results obtained from the survey. To make sure that the presented results are reliable for the entire survey (Q1-15) and separately for the second (Q1-10) and third (Q11-15) parts, the Crombach test was performed. This coefficient was described by Lee Cronbach in Coefficient Alpha and the Internal Structure of Tests. The Cronbach alpha test is a commonly used method of analysing the reliability of given scales, which was presented, inter alia, in research works (Bonett and Wright, 2015; Cho and Kim, 2015; Ciavolino et al., 2020; Ingaldi and Klimecka-Tatar, 2020; Taber, 2018).

Based on the analysis, it was found that the Cronbach's coefficient for the entire survey is 0.846 , which indicates high confidence (reliability), while for individual parts: the second part (Q1-10) 0.711 , and for the third part (Q11-15) only 0.499 . It is easy to notice that the Cronbach's coefficient for the third part is very low and may undermine the statistical distribution of the answers - the tested scale contains questions concerning more than one construct. However, the results obtained in this part, the socio-economic situation in the period of the crisis in 2020, make it possible to be considered correct. Which was also confirmed by the correlation coefficients between the questions of the two parts of the questionnaire. 
Table 2.

Descriptive statistical analysis of questions aimed at identifying a limitation in the availability of everyday products (Q1-10)

\begin{tabular}{lrrrrrrrrrr}
\hline & Q1 & Q2 & Q3 & Q4 & Q5 & Q6 & Q7 & Q8 & Q9 & Q10 \\
\hline Mean value & 3.68 & 4.28 & 3.81 & 3.79 & 2.43 & 2.47 & 3.08 & 1.81 & 1.79 & 2.74 \\
Standard error & 0.15 & 0.13 & 0.14 & 0.17 & 0.13 & 0.16 & 0.21 & 0.12 & 0.09 & 0.13 \\
Median & 3.00 & 5.00 & 4.00 & 4.00 & 3.00 & 2.00 & 3.00 & 2.00 & 2.00 & 3.00 \\
Standard deviation & 1.12 & 0.97 & 1.04 & 1.23 & 0.97 & 1.19 & 1.53 & 0.88 & 0.66 & 0.92 \\
Sample variance & 1.26 & 0.94 & 1.08 & 1.51 & 0.94 & 1.41 & 2.34 & 0.77 & 0.44 & 0.85 \\
Kurtosis & -1.03 & 2.58 & -0.61 & -0.73 & 0.32 & -0.42 & -1.56 & 1.66 & -0.69 & 0.48 \\
Skewness & -0.17 & -1.66 & -0.35 & -0.68 & 0.32 & 0.50 & 0.10 & 1.09 & 0.25 & -0.05 \\
Minimum & 1.00 & 1.00 & 1.00 & 1.00 & 1.00 & 1.00 & 1.00 & 1.00 & 1.00 & 1.00 \\
Maximum & 5.00 & 5.00 & 5.00 & 5.00 & 5.00 & 5.00 & 5.00 & 5.00 & 3.00 & 5.00 \\
\hline
\end{tabular}

Source: own study

Table 3.

Descriptive statistical analysis of questions focused on anxiety and a disturbed sense of security (Q11-15)

\begin{tabular}{lrrrrr}
\hline & Q11 & Q12 & Q13 & Q14 & Q15 \\
\hline Mean value & 3.91 & 3.89 & 2.64 & 2.47 & 2.19 \\
Standard error & 0.16 & 0.15 & 0.17 & 0.16 & 0.18 \\
Median & 4.00 & 4.00 & 3.00 & 2.00 & 2.00 \\
Standard deviation & 1.20 & 1.12 & 1.23 & 1.14 & 1.32 \\
Sample variance & 1.43 & 1.26 & 1.50 & 1.29 & 1.73 \\
Kurtosis & -0.43 & -0.52 & -0.69 & 0.23 & -0.51 \\
Skewness & -0.79 & -0.71 & 0.34 & 0.77 & 0.85 \\
Minimum & 1.00 & 1.00 & 1.00 & 1.00 & 1.00 \\
Maximum & 5.00 & 5.00 & 5.00 & 5.00 & 5.00 \\
\hline
\end{tabular}

Source: own study

As it results from the data presented in Table 2 (questions aimed at identifying a limitation in the availability of everyday products (Q1-10)) and from their graphical analysis in Figure 1, the respondents during the lockdown noted the greatest limited availability of food products and in particular fresh fruit and vegetables. For the question Q2 (Is the availability of fresh vegetables and fruit limited?) the average value of the answer is 4.28. However, for other food products the values are slightly lower. For the question Q1 (Is the availability of bread limited?) the mean value of the answer is 3.68, for Q3 (Is the availability of dairy products limited?) the mean value of the answer is 3.81, for the question Q4 (Is the availability of meat products limited?) the mean value of the answer is 3.79. It can be assumed that the mean values for Q1, 3 and 4 are comparable - they are within the standard error limit.

The lowest mean value of the answer was obtained for question Q8 (Is the availability of supplements limited?) and Q9 (Is the availability of tobacco and alcohol products limited?). The respondents confirmed that they did not feel the limited availability of supplements and stimulants such as alcohol and tobacco products - the lack of feeling of limited availability to these products results from the fact that they are not necessities, and/or they are not used by the respondents. The mean values of responses for questions Q8 and Q9 can be considered comparable (for Q8 about 1.81, for Q9 about $1,79)$ - the values are within the standard error limit. Additionally, it was observed that for question $Q 9$ there were no grades higher than 3 .

The availability of pharmaceuticals was also rated slightly above the middle of the scale - the mean value of the answer for Q7 (Is the availability of pharmaceuticals limited?) is 
3.08. While the availability of other products (household chemicals, hygiene products, clothing products) seems to be indifferent to the respondents.

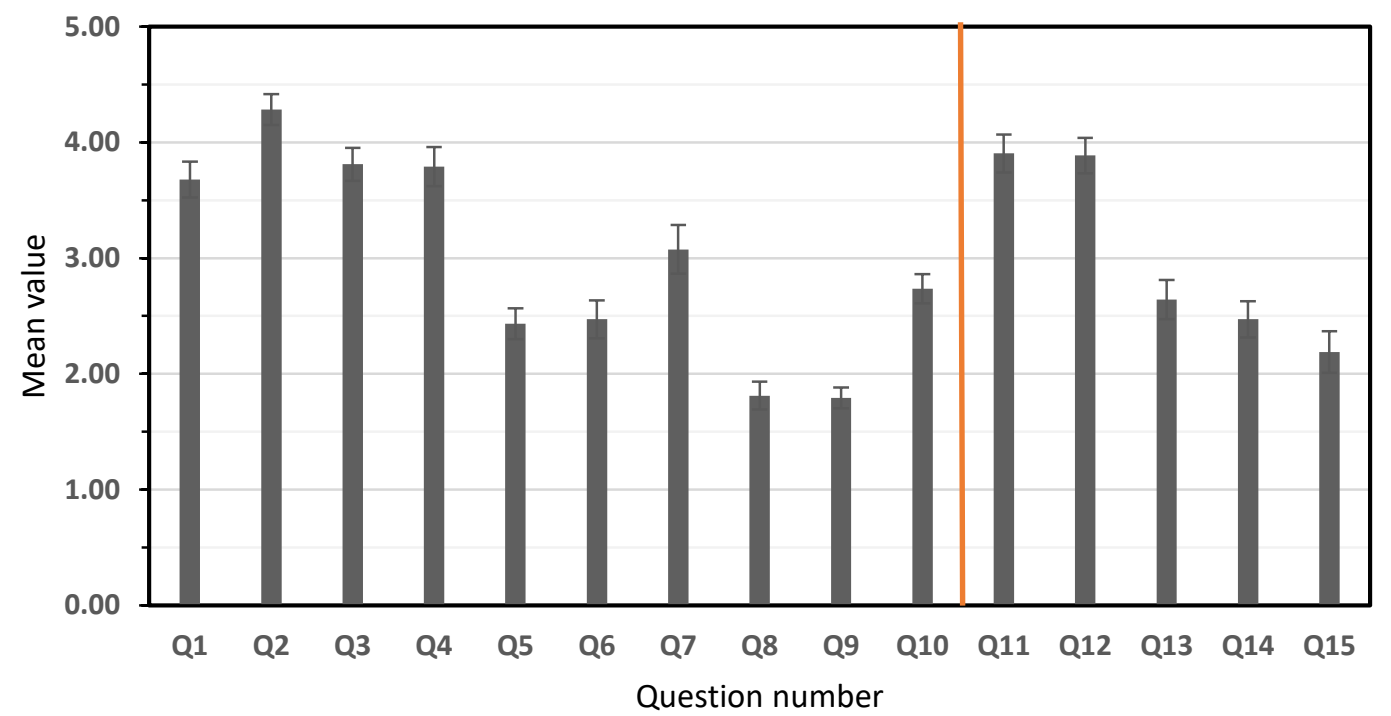

Fig. 1. The mean value of the note on the basis of a 5-point Likert scale for the questions aimed at identifying a limitation in the availability of everyday products $(\mathrm{Q} 1-10)$ and questions focused on anxiety and a disturbed sense of security (Q11-15). Note 1 means (Q1-10/Q1115): "I did not feel limited availability at all"/ "I feel very safe"; 5 means: "I feel limited availability very much"/"I feel very great danger"

Source: own study

As it results from the data presented in Table 3 (questions focused on anxiety and a disturbed sense of security (Q11-15) and from their graphical analysis in Figure 1, it can be observed that the respondents feel the greatest anxiety about limited availability of food products and pharmaceutical products. For question Q11 (Do you feel insecure due to the limited availability of food products?) and Q12 (Do you feel insecure due to the limited availability of pharmaceutical products?), comparable mean values were recorded, 3.91 and 3.89 respectively. On the other hand, the respondents assessed anxiety and insecurity related to access to other product groups (household chemicals, hygiene products, clothing products) below the middle of the scale - that is, they treated these limitations indifferently.

In order to determine the correlation between the variables, a correlation matrix was developed for the two parts of the survey (Q1-15) - the correlation matrix is presented in Table 4. In Table 4, significant positive correlations are marked (highlighted), where the correlation coefficient takes values $r>0.5$. Regarding the second part of the questionnaire (Q1-10), it can be stated that the answers to question Q1 (Is the availability of bread limited?) are strongly correlated with the answers to questions Q2 (Is the availability of fresh vegetables and fruit limited?), Q3 (Is the availability of dairy products limited?) Q4 (Is the availability of meat products limited?), Q7 (Is the availability of pharmaceuticals limited?). Similarly, the answers to question Q2 are strongly correlated with the answers to the questions Q3, Q4, Q7, the answers to the question Q3 are strongly correlated with the answers to the questions Q4, Q7, and the question Q4 with the answers to the question Q7. Which indicates that respondents who said there was limited access to bread also saw limited access to other food 
products, such as fresh vegetables and fruit, dairy products and meat products. The same respondents noted that there is limited access to pharmaceuticals. The highest value of the correlation coefficient was noted between the answers to questions $Q 1$ and Q3, where $r=0.953$.

Table 4.

Correlation matrix for answers to questions Q1-15 (współczynnik korelacji -1 $r \leq 1$ )

\begin{tabular}{|c|c|c|c|c|c|c|c|c|c|c|c|c|c|c|c|}
\hline & Q1 & Q2 & Q3 & Q4 & Q5 & Q6 & Q7 & Q8 & $Q 9$ & Q10 & Q11 & Q12 & Q13 & Q14 & Q15 \\
\hline Q1 & 1.000 & & & & & & & & & & & & & & \\
\hline Q2 & 0.651 & 1.000 & & & & & & & & & & & & & \\
\hline Q3 & 0.953 & 0.589 & 1.000 & & & & & & & & & & & & \\
\hline Q4 & 0.717 & 0.631 & 0.706 & 1.000 & & & & & & & & & & & \\
\hline Q5 & 0.324 & 0.235 & 0.292 & 0.222 & 1.000 & & & & & & & & & & \\
\hline Q6 & 0.462 & 0.417 & 0.417 & 0.345 & 0.253 & 1.000 & & & & & & & & & \\
\hline Q7 & 0.821 & 0.582 & 0.796 & 0.673 & 0.366 & 0.372 & 1.000 & & & & & & & & \\
\hline Q8 & -0.160 & -0.275 & -0.229 & -0.250 & -0.105 & 0.179 & -0.419 & 1.000 & & & & & & & \\
\hline Q9 & -0.066 & -0.267 & -0.142 & -0.101 & 0.143 & -0.093 & -0.079 & 0.296 & 1.000 & & & & & & \\
\hline Q10 & 0.047 & -0.087 & 0.087 & -0.032 & -0.149 & 0.063 & 0.001 & 0.032 & -0.344 & 1.000 & & & & & \\
\hline Q11 & 0.721 & 0.637 & 0.635 & 0.639 & 0.383 & 0.601 & 0.623 & 0.019 & 0.194 & -0.110 & 1.000 & & & & \\
\hline Q12 & 0.460 & 0.314 & 0.394 & 0.415 & 0.329 & 0.446 & 0.588 & -0.081 & 0.201 & 0.082 & 0.537 & 1.000 & & & \\
\hline Q13 & 0.320 & 0.136 & 0.218 & 0.179 & 0.553 & 0.304 & 0.281 & 0.079 & 0.073 & 0.068 & 0.304 & 0.446 & 1.000 & & \\
\hline Q14 & 0.061 & -0.124 & -0.005 & -0.052 & 0.107 & 0.003 & 0.001 & 0.149 & 0.082 & -0.062 & 0.118 & 0.163 & 0.206 & 1.000 & \\
\hline Q15 & 0.133 & 0.033 & 0.125 & 0.132 & 0.130 & 0.151 & 0.060 & 0.081 & -0.043 & -0.022 & 0.036 & 0.223 & 0.209 & 0.351 & 1.000 \\
\hline
\end{tabular}

Source: own study

Additionally, a negative value of the correlation coefficient was noted between questions Q7 (Is the availability of pharmaceuticals limited?) and Q8 (Is the availability of supplements limited?). Which means that people who confirmed limited access to pharmaceuticals did not notice (or did not consider it important) limited access to supplements. On the other hand, question Q9 (Is the availability of tobacco and alcohol products limited?) is slightly, negatively correlated with question Q10 (Is the availability of clothing products limited?).

The next stage of the analysis is to find out how the answers to the questions in the third part of the questionnaire correlate with each other (questions focused on anxiety and a disturbed sense of security (Q11-15)). In this case, a positive correlation was only observed between the answers to the question Q11 (Do you feel insecure due to the limited availability of food products?) and Q12 (Do you feel insecure due to the limited availability of pharmaceutical products?). Which means that people who feel anxious about limited access to fresh bread also feel anxious about limited access to pharmaceuticals.

The correlation of responses to the questions from two parts of the questionnaire was also analysed, i.e. it was determined how the limitation in access to products of everyday use affects the sense of anxiety and security of the respondents. A significant (positive) correlation was observed between the answers to question Q11 (Do you feel insecure due to the limited availability of food products?) in relation to the answers to the questions concerning the availability of food products (Q1-4), but also the availability of hygiene product and pharmaceuticals (Q6 and 7). It has been noticed that people who rate Q5 highly, found out that access to households chemicals is limited feel anxious and threatened with it. Similarly, people who rated question Q7 highly, feel anxious and threatened by limited access to pharmaceuticals. 
The obtained results of the analysis confirm that the society underwent a panic (right and justified) (Islam et al., 2020; Yu, et al., 2021). Interestingly, an in-depth analysis of the received responses in relation to the characteristics of the respondents showed that significantly higher scores (in both parts of the questionnaire) were given by older people from smaller towns and with a lower social status. This tendency may be the result of the fact that people in smaller towns and villages mainly buy in small retail stores. In the pandemic period, the largest decrease in sales volume is recorded in small retail stores - the reasons can be experienced due to the introduction of strong security restrictions and the inability to change the sales mode, e.g. via the Internet. The impact of restrictions on the operation of small retail stores has been described in numerous publications (Avtar, et al., 2021; Cavallo, et al., 2020; Ingaldi and Brožovà, 2020; Mehta, et al., 2020; Pantano, et al., 2020; Roggeveen and Sethuraman, 2020; Talwar, et al., 2021)

\section{CONCLUSION}

Based on the research conducted with the use of the questionnaire and the results of the analysis of the value of answers to the questions aimed at identifying a limitation in the availability of everyday products (Q1-10) and questions focused on anxiety and a disturbed sense of security (Q11-15), it was found that during the lockdown caused by the epidemic situation, people feel limited access to some products of everyday life, which in turn has an impact on their sense of anxiety and security. It was found that:

- the respondents during the lockdown noted the greatest limited availability of food products and in particular fresh fruit and vegetables, also found limited access to bread, dairy and meat products (limited access at a comparable level);

- the respondents confirmed that they did not feel the limited availability of supplements and stimulants such as alcohol and tobacco products - the lack of feeling of limited availability to these products probably results from the fact that they are not necessities, and are not used by the respondents;

- the respondents also reported limited access to pharmaceuticals;

- the availability of other products (household chemicals, hygiene products, clothing products) seems to be indifferent to the respondents;

- the respondents who said there was limited access to bread also saw limited access to other food products, such as fresh vegetables and fruit, dairy products and meat products. The same respondents noted that there is limited access to pharmaceuticals;

- for the respondents, the main reason for anxiety and insecurity turned out to be limited access to food products,

- people who feel anxious about limited access to fresh bread also feel anxious about limited access to pharmaceuticals

\section{ACKNOWLEDGEMENTS}

Research and publication were financed by the statutory research fund of the Czestochowa University of Technology BS/PB-600/3010/2020 


\section{REFERENCES}

Albonico, A., Tirelli, P., 2020. Financial crises and sudden stops: Was the European monetary union crisis different? Economic Modelling, 93, 13-26, DOI: 10.1016/j.econmod.2020.06.021

Avtar, R., Singh, D., Umarhadi, D. A., Yunus, A. P., Misra, P., Desai, P. N., Phanindra, K., 2021. Impact of COVID-19 Lockdown on the Fisheries Sector: A Case Study from Three Harbors in Western India, Remote Sensing, 13(2), 183, DOI: 10.3390/rs13020183

Baryshnikova, N., Kiriliuk, O., Klimecka-Tatar, D., 2020. Management approach on food export expansion in the conditions of limited demand, Polish Journal of Management Studies, 21(2), 101-114. DOI: 10.17512/pjms.2020.21.2.08

Baryshnikova, N., Kiriliuk, O., Klimecka-Tatar, D., 2021. Enterprises' strategies transformation in the real sector of the economy in the context of the COVID-19 pandemic, Production Engineering Archives, 27(1), 8-15, DOI: 10.30657/pea.2021.27.2

Blenkinsop, P., 2020. Coronavirus could reduce world trade by up to a third, according to the WTO, Https://www.Weforum.Org/agenda/2020/04/wto-Financial-CrisisCoronavirus-Covid19-Recession-Trade-Global.

Bonett, D. G., Wright, T. A., 2015. Cronbach's alpha reliability: Interval estimation, hypothesis testing, and sample size planning, Journal of Organizational Behavior, 36(1), 3-15, DOI: 10.1002/job.1960

Bove, L. L., Benoit, S., 2020. Restrict, clean and protect: signaling consumer safety during the pandemic and beyond. Journal of Service Management, 31(6), 11851202, DOI: 10.1108/JOSM-05-2020-0157

Burdekin, R. C., Tao, R., 2020. The Golden Hedge: From Global Financial Crisis to Global Pandemic, Economic Modelling. Advance online publication, DOI: 10.1016/j.econmod.2020.12.009

Cavallo, C., Sacchi, G., Carfora, V., 2020. Resilience effects in food consumption behaviour at the time of Covid-19: Perspectives from Italy, Heliyon, 6(12), e05676, DOI: 10.1016/j.heliyon.2020.e05676

Chen, Y.-L., Ting, H.-I., Wang, M.-C. 2020. Government support and bank performance during the 2007-2008 financial crisis, The North American Journal of Economics and Finance, 101301, DOI: 10.1016/j.najef.2020.101301

Cho, E., Kim, S., 2015. Cronbach's Coefficient Alpha, Organizational Research Methods, 18(2), 207-230, DOI: 10.1177/1094428114555994

Ciavolino, E., Lagetto, G., Montinari, A., Al-Nasser, A. D., Al-Omari, A. I., Zaterini, M. J., Salvatore, S., 2020. Customer satisfaction and service domains: a further development of PROSER,. Quality \& Quantity, 54(5-6), 1429-1444, DOI: $10.1007 / \mathrm{s} 11135-019-00888-4$

Čierna, H., Sujová, E., 2020. Integrating Principles of Excellence and of Socially Responsible Entrepreneurship, Management Systems in Production Engineering, 28(1), 23-28, DOI: 10.2478/mspe-2020-0004

Contreras, L. E. V., Perkins, K. M., Ellenbecker, M., Moure-Eraso, R., Vega, N. E. M., 2020. Covid-19 Pandemic Lessons to Facilitate Future Engagement in the Global Climate Crisis. Journal of Cleaner Production, 125178, DOI: 10.1016/j.jclepro.2020.125178 
Gajdzik, B., Wolniak, R. 2021. Influence of the COVID-19 Crisis on Steel Production in Poland Compared to the Financial Crisis of 2009 and to Boom Periods in the Market, Resources, 10(1), 4, DOI: 10.3390/resources10010004

Gugler, K., Weichselbaumer, M., Zulehner, C., 2020. Employment behavior and the economic crisis: Evidence from winners and runners-up in procurement auctions. Journal of Public Economics, 182, 104112, DOI: 10.1016/j.jpubeco.2019.104112

Ingaldi, M., Brožovà, S., 2020. Popularity of E-Shops During the Covid-19 Pandemic, Conference Quality Production Improvement, 2(1), 1-10, DOI: 10.2478/cqpi-20200001

Ingaldi, M., Klimecka-Tatar, D., 2020. People's Attitude to Energy from HydrogenFrom the Point of View of Modern Energy Technologies and Social Responsibility, Energies, 13(24), 6495, DOI: 10.3390/en13246495

Ingaldi, M., Ulewicz, R., 2019. How to Make E-Commerce More Successful by Use of Kano's Model to Assess Customer Satisfaction in Terms of Sustainable Development, Sustainability, 11(18), 4830, DOI: 10.3390/su11184830

Islam, T., Pitafi, A. H., Arya, V., Wang, Y., Akhtar, N., Mubarik, S., Xiaobei, L., 2020. Panic buying in the COVID-19 pandemic: A multi-country examination, Journal of Retailing and Consumer Services, 102357, DOI: 10.1016/j.jretconser.2020.102357

Klimecka-Tatar, D., Ingaldi, M., 2020. Service quality management in term of IHRM concept and the employee internationalization, International Journal for Quality Research, in publish, DOI: 10.24874/IJQR15.03-05

Knop, K., 2020. Indicating and analysis the interrelation between terms - visual: management, control, inspection and testing. Production Engineering Archives, 26(3), 110-120, DOI: 10.30657/pea.2020.26.22

Kowalik, K., 2020. The role of safety in service quality in the opinion of traditional and digital customers of postal service, Production Engineering Archives, 26(1), 1-4, 10.30657/pea.2020.26.01

Labajan, R. A. A., Koomsap, P., 2019. Customer Journey Clue-based Service Failure Prevention, Production Engineering Archives, 25(25), 21-34, DOI: 10.30657/pea.2019.25.05

Lang, B., Dolan, R., Kemper, J., Northey, G., 2020. Prosumers in times of crisis: definition, archetypes and implications. Journal of Service Management, ahead-ofprint(ahead-of-print), 254, DOI: 10.1108/JOSM-05-2020-0155

Le, D., Phi, G., 2020. Strategic responses of the hotel sector to COVID-19: Toward a refined pandemic crisis management framework, International Journal of Hospitality Management, 102808, DOI: 10.1016/j.jjhm.2020.102808

Mehta, S., Saxena, T., Purohit, N., 2020. The New Consumer Behaviour Paradigm amid COVID-19: Permanent or Transient? Journal of Health Management, 22(2), 291-301, DOI 10.1177/0972063420940834

Moyo, N., 2020. Antecedents of employee disengagement amid COVID-19 pandemic. Polish Journal of Management Studies, 22(1), 323-334, 10.17512/pjms.2020.22.1.21

Nakat, Z., Bou-Mitri, C., 2021. Covid-19 and the food industry: Readiness assessment. Food Control, 121, 107661, DOI: 10.1016/j.foodcont.2020.107661

O'Hara, S., Toussaint, E. C., 2021. Food access in crisis: Food security and COVID19. Ecological Economics, 180, 106859, DOI: 10.1016/j.ecolecon.2020.106859

Okeagu, C. N., Reed, D. S., Sun, L., Colontonio, M. M., Rezayev, A., Ghaffar, Y. A., (...) Kaye, A. D., 2020. Principles of supply chain management in the time of crisis, Best 
Practice \& Research Clinical Anaesthesiology, Advance online publication, DOI: 10.1016/j.bpa.2020.11.007

Pantano, E., Pizzi, G., Scarpi, D., Dennis, C., 2020. Competing during a pandemic? Retailers' ups and downs during the COVID-19 outbreak, Journal of Business Research, 116, 209-213, DOI: 10.1016/j.jbusres.2020.05.036

Pietraszek, J., Radek, N., Goroshko, A.V., 2020. Challenges for the DOE methodology related to the introduction of Industry 4.0, Production Engineering Archives, 26(4), 190-194, DOI: 10.30657/pea.2020.26.33

Ritchie, B. W., Jiang, Y., 2019. A review of research on tourism risk, crisis and disaster management: Launching the annals of tourism research curated collection on tourism risk, crisis and disaster management, Annals of Tourism Research, 79, 102812, DOI: 10.1016/j.annals.2019.102812

Ritter, T., Pedersen, C. L., 2020. Analyzing the impact of the coronavirus crisis on business models, Industrial Marketing Management, 88, 214-224, DOI: 10.1016/j.indmarman.2020.05.014

Roggeveen, A. L., Sethuraman, R., 2020). How the COVID-19 Pandemic May Change the World of Retailing, Journal of Retailing, 96(2), 169-171, DOI: 10.1016/j.jretai.2020.04.002

Rosak-Szyrocka, J., Abbase, A. A., 2020. Quality management and safety of food in HACCP system aspect, Production Engineering Archives, 26(2), 50-53, DOI: 10.30657/pea.2020.26.11

Taber, K. S., 2018. The Use of Cronbach's Alpha When Developing and Reporting Research Instruments in Science Education, Research in Science Education, 48(6), 1273-1296, DOI: 10.1007/s11165-016-9602-2

Talwar, M., Talwar, S., Kaur, P., Tripathy, N., Dhir, A., 2021. Has financial attitude impacted the trading activity of retail investors during the COVID-19 pandemic? Journal of Retailing and Consumer Services, 58, 102341, DOI: 10.1016/j.jretconser.2020.102341

Wawrowski, B., Otola, I. 2020. Social Media Marketing in Creative Industries: How to Use Social Media Marketing to Promote Computer Games? Information, 11(5), 242, DOI: 10.3390/info11050242

Yu, Y. J., Park, Y. S., Keller, A., Noh, J.-W., Cha, J. 2021. A Mixed-Methods Systematic Review of the Impacts of Coronavirus on Society and Culture, International Journal of Environmental Research and Public Health, 18(2), 491, DOI: 10.3390/ijerph18020491 